Open Access

\title{
Determinants of loan repayment among agricultural microcredit finance group members in Delta state, Nigeria
}

\author{
Solomon Enimu*, Emmanuel O. Eyo and Eucharia A. Ajah
}

\author{
* Correspondence: \\ solomonenimu@gmail.com \\ Department of Agricultural \\ Economics, University of Calabar, \\ Cross River State, Calabar, Nigeria
}

\begin{abstract}
Background: This study examined the determinants of loan repayment among microcredit finance group members in Delta State, Nigeria.

Methods: To capture the determinants of loan repayment in the study area, a total of 48 microcredit groups and 300 microcredit group members were randomly selected through a multi-stage random sampling technique. The study data was collected by questionnaire. Statistical tools such as simple descriptive statistics (table, frequency, percentage and mean) and a multiple regression analysis were used to examine the data.

Results: The results indicate that females form a greater proportion of the study area microcredit group members at $70 \%$, moreover $73 \%$ of the respondents have a household size of between 6 to 10 persons. These findings revealed that the groups had a mean 8 years of existence with a mean membership size of 13 persons. Further, an average interest rate of 40 percent per annum was charged on loans, with mean loan duration of 6 months. The regression's result demonstrated that the determinants of the group member's loan repayment included the group member's age, household size, house income, and educational level, the amount of credit received, length of stay in their locality, distance to the credit source, supervision and disbursement lag.

Conclusion: Therefore it was suggested that the various agricultural microcredit finance groups should carefully examine the significant determinants of loan repayment for the approach's viability and sustainability and for optimum repayment performance.
\end{abstract}

Keywords: Determinants, Loan repayment, Microcredit, Groups, Members, Delta state

\section{Background}

Microcredit is an important interventionist strategy in this decade of global economic liberalization, as it is designed to address and ameliorate financial markets by providing credit without collateral to those in rural area (Aterido, Beck and Lacovone, 2011). Nigeria's 1986 economic liberalization as in many other countries exacerbated the financial problems in the rural sector. Loan funds from formal markets dwindled and borrowing costs escalated while the financial outlays for business enterprises multiplied several-fold due to the ravage of inflation such that only a limited number of entrepreneurs could meet their financial obligations, (Eyo, 2008).

(c) The Author(s). 2017 Open Access This article is distributed under the terms of the Creative Commons Attribution 4.0 International License (http://creativecommons.org/licenses/by/4.0/), which permits unrestricted use, distribution, and reproduction in any medium, provided you give appropriate credit to the original author(s) and the source, provide a link to the Creative Commons license, and indicate if changes were made. 
Microfinance has become a major tools used to extend credit to many low income entrepreneurs in developing countries. The provision of microcredit services improves the latent capacity of the poor for entrepreneurship thus enabling their increased selfreliance, increasing their capacity to create more employment opportunities and ultimately enhancing household income and creating wealth (Allen, Demirguc-Kunt, Klapper and Martinez-Peria, 2012). However, several authors (Ghatak, 1999; Soren, 2002; Campbell, 2006; Eyo, Otu and Sampson, 2008; Mkpado, Idu and Arene, 2010; Demirguc-Kunt and Klapper, 2012) indicate that financial institutions in recent years have preferred to disburse credit to micro entrepreneurs in groups to solve the menace of low repayments rates and high transaction costs. This is particularly true of the Nigerian financial market and micro entrepreneurs in the agricultural sector.

Group lending involves the administration of credit among groups whose individuals differ in characters and reactions but who possess a common interest, in that they benefit from the group (Hulme and Mosely, 1996). The pattern of membership composition is judged as important for groups' increased performance in terms of repayment as well as savings mobilization and the building of social cohesion through attendance at regular meetings, among other activities, (Aryeety and Udry, 1997). A greater probability exists that members will conform to group objectives in homogenous group where individual members have similar interest and share similar problems than in heterogeneous groups.

\section{Statement of problem}

Group lending in Nigeria has a long history as it descend from the lending activities of several Informal finance groups that existed in the nation's communities before modern cooperative societies. These groups mobilized their savings and used the consequent funds to provide loans for their members; these groups' existence has been the basis over time for Nigeria's robust informal financial market, (Udo, 1995; Eyo, 1997). It became obvious in the late 1980s, that a major set-back of the Agricultural Credit Guarantee Fund Scheme (ACGFS) was the non performance of loans it guaranteed, which discouraged commercial banks from extending credit to the agricultural sector. The Central Bank of Nigeria reversed this trend by introducing a group-lending approach in 1991that linked banks with savings and credit associations and informal groups. The formal-informal sector linkage under the ACGFS began its operations in 1992, and has become a preference of formal lenders over time for its lending to farmers to overcome transaction costs and loan default issues.

Clearly, microfinance providers in Nigeria enhance increased access to credit for many farmers. However, several authors (Oludimu, 1983; Eyo, 2008; Olagunju and Adeyemo, 2007; Enimu and Ohen, 2017) have indicated that formal finance schemes that reach out to their clients in groups do not automatically achieve satisfactory performance. Alternatively some of these programs have indicated limited success. For example, Eyo (2002) reports that groups that enlisted in the informal-formal sector linkage only recorded a $63 \%$ repayment rate by 1998 when an association of self-help groups began in 1998, a clear problem of the linkage program involved how to improve loan repayment by groups. Currently, institutions in this linkage have been blamed and accused of inefficiency in meeting the demands of smaller loan holders, (Igben and Enimu, 2016). Nonetheless, these institutions assume an enormous social cost that continues to increase. Supported by the government through loan refinancing, these institutions are encumbered with serious 
problems of loan in arrears and institutional non-viability. This is further evidenced by the persistence of issues that led to the establishment of such programs, such as the low mobilization of savings, the improper use of conventional banks services and inadequate rural credit deliveries to rural small scale producers, as exemplified by financial exclusion. (Enimu, Igiri and Achike, 2016; Okorie, 1986; and Okafor, 2000).

\section{The study's justification}

Nigeria records a low level of financial inclusion, which culminated in the adoption of a national financial inclusion strategy to achieve a 70\% inclusion by the year 2020. The World Bank (2000) estimated that the Nigerian Agricultural Co-Operative Bank, The Peoples Bank of Nigeria, and community banks could only reach less than $10 \%$ of the rural population during their total existence. Further, Ajakaiye (2013) indicates that only $30 \%$ of Nigerian adults have an account with formal financial institutions. Farmers in Delta State as with many other states in Nigeria with microfinance institutions and group lending schemes still cite the lack of adequate credit as one constraint to increased agricultural production, (Mbah, 2009; Afolabi, 2010; Eyo and Enimu 2015; Enimu, Igiri and Uduma, 2015). However, micro-financial institutions activities are a good source of financing resources, as constrained poor farmers abound these activities should benefit the farmers as well as the nation in its quest for financial inclusion. Regarding a formalinformal sector linkage, group performance in meeting the group's financial obligations to the partner bank is a function of the group member's ability to repay group loans. Invariably, loan beneficiaries' inability to repay their loans makes it impossible for the lenders to meet their other clients' demands, thereby negatively impacting outreach and financial inclusion. More over, for the credit system to function, both effectively and efficiently, it is important that a default in repayment is as rare as possible, as the agencies' viability highly depends on the loan amounts recovered.

Group members must behave predictably in meeting financial obligations with their partner banks to sustain group lending. This implies that the design of microfinance institutions' lending programs must be fine-tuned to ensure group members' compliance. The determinants of loan repayment among agricultural microcredit finance group members in Nigeria's Delta State must be analyzed to properly guide the market. This is particularly important now, in that credits to alleviate rural poverty have been a current focus of most international organizations such as the Food and Agriculture Organization, the United Nations Development Programme, the World Bank and the African Development Bank. Such organizations are involved in the war against poverty and food security in developing countries and the economic improvement of resources, including poor farmers' access to credit and other financial services is one major avenue through which their output will improve. This study's results will enable all interested government agencies and organs involved in the formulation of credit policies and group-oriented programs to form an opinion on using either the microfinance approach, or a modification of its concepts and operational mechanism for the delivery of micro/rural financial services in developing countries in general, and Nigeria in particular.

\section{Objective of the study}

This study's broader objective is to examine the determinants of loan repayment among microcredit finance group members in the study area. The specific objectives include: 
$>$ describing the group members' socio-economic characteristics;

$>$ determining microcredit finance groups' operational characteristics; and

$>$ analyzing the determinants of loan repayments among the microcredit finance

group members.

\section{The study's hypothesis}

The study was guided by the following hypothesis:

No significant relationship exists between the captured determinants of loan repayment and the amount of loans repaid by microcredit group members.

\section{Analytical framework}

The intra-group risk pooling in agricultural microcredit groups occurs in anticipation of some benefits. Invariably, it is assumed that members of a group will maximize their utility function relative to the expected net benefits, which are derived from participating in the group. These benefits occur in the form of financial services through access to group funds and co-insurance. Cohesive group membership with moral ties is a form of social collateral which manifests as joint liability and the reciprocity of obligations in times of need (Yunus 1999; Schreiner and Nagarajan, 1997).

The group's performance is affected by membership composition, which influences the availability of information and risks due to covariance in membership design and determinants. According to Nagaranjan, Meyer, and Graham (1999), membership composition can be homogeneous or heterogeneous, but the members' heterogeneity significantly influences the information needed to reduce costs. Therefore, it can be posited that repayment performance may significantly depend on membership composition. This specification extends models proposed by Slover (1991), and has been successfully applied by Sharma and Zeller (1997); and Paxton (1996); in Gambia by Nagaranjan, Meyer, and Graham (1999), and in Nigeria by Olomola (2002), Ugbomeh, Achoja, Ideh, and Ofuoku (2008), and Enimu and Ohen (2017).

\section{Methods}

Study area; sampling and data collection

This study focused on agricultural microcredit finance groups in Delta State, the cradle of wetland agriculture and the microfinance movement in Nigeria. The state occupies an area of approximately $17,011 \mathrm{~km}^{2}$ and lies between the latitude $5^{0} 00^{1}$ and $6^{0} 30^{1} \mathrm{~N}$ and longitude $5^{0} 00^{1}$ and $6^{0} 45^{1} \mathrm{E}$. The state is generally characterized by a wide expanse of flood plain and swampy terrain in the southern and central agricultural zones, while the northern agricultural zone is hilly. A 2006 population census denotes over 4.1 million people, of which $75 \%$ work in the agricultural sector. Agriculture in the state is characterized by sole proprietorship with some form of specialization. Delta State is located within a tropical region, with two main seasons. Although most literature indicates that the area has an approximately nine-month rainy season with a three-month dry season, rain can fall throughout the year. According to the Meteorological Division of the Federal Ministry of Aviation Asaba, rainfall is typically heavy in July ranging between $2667 \mathrm{~m}$ along the coast to approximately $1905 \mathrm{~m}$ on the Northern Fringe. 
Vegetation consists of mangrove swamp forest along the coastal areas, thick rainforest in the middle hinterlands and the savannah in the north. The soil is essentially sandy loam, which favors a wide variety of agricultural activities including crop and livestock production. Common crops and livestock include cassava, plantains, bananas, poultry, piggery, cattle and vegetables and fruits.

This land is also suitable for wildlife conservation, fish farming, and artisanal fishing. Generally, agriculture is undertaken on a full or part-time basis. People in the coastal areas primarily work in fishing, but also undertake various trades as supplementary occupations. A majority of farming and fishing activities are in small scale and involve microfinance; informal financial markets are a significant source of the loans available to these small-scale operators.

\section{Data source}

This study was both primary and secondary data. Primary data was obtained through a well-structured questionnaire, complemented by oral interview by fully trained enumerators to elicit information on the groups' operating dynamics and socio-economic characteristics/ determinants, Secondary data was obtained from the microfinance groups' statement of accounts and financial reports, as well as the microfinance banks' financial statements and the Central Bank of Nigeria's financial reports and statements, both published and unpublished.

\section{Sampling procedure and data analysis}

A multi-stage random sampling technique was applied in the sample selection, and a proportionate sampling method was used, with 48 microcredit finance groups and 300 microcredit group members randomly selected for the study. The data analysis included descriptive statistical tools and a multiple regression analytical technique.

\section{The empirical model}

The regression model used postulated that the group members' loan repayment amount (LR) is a function of the respondents' age (A), his or her household size $(\mathrm{H})$, educational level (E) in years, the amount of money borrowed $(M)$ in Nigeria naira, the duration of the group's existence (D) in years, the length of time in the community $(C)$ in years, the distance to the credit source $(\mathrm{S})$, in kilometer, the value of interest charged $(\mathrm{V})$, as a percentage, household income (i) in naira, loan supervision $(\mathrm{P})$ as the number of visits, disbursement lag (G), in the numbers of days and gender (GD), as a dummy.

Consequently, the mathematical model is expressed as

$$
\mathrm{LR}=\mathrm{f}(\mathrm{A}, \mathrm{H}, \mathrm{E}, \mathrm{M}, \mathrm{D}, \mathrm{C}, \mathrm{S} \mathrm{V}, \mathrm{I} \mathrm{P}, \mathrm{G}, \mathrm{GD})
$$

The a priori expectation is that

$$
\mathrm{LR}=\mathrm{a}+\mathrm{a}_{1} \mathrm{~A}-\mathrm{a}_{2} \mathrm{H}+\mathrm{a}_{3} \mathrm{E}+\mathrm{a}_{4} \mathrm{M}+\mathrm{a}_{5} \mathrm{D}+\mathrm{a}_{6} \mathrm{C}-\mathrm{a}_{7} \mathrm{~S}-\mathrm{a}_{8} \mathrm{~V}+\mathrm{a}_{9} \mathrm{I}+\mathrm{a}_{10} \mathrm{P}-\mathrm{a}_{11} \mathrm{G}-\mathrm{a}_{12} \mathrm{GD}
$$

where $\mathrm{a}_{\mathrm{o}}$ is a constant, and $\mathrm{a}_{1}-\mathrm{a}_{12}$ are the parameters.

A multiple regression analysis was used to determine the factors that influence loan repayment among microcredit finance group members with ordinary least squares estimates used to estimate the regression model. The ordinary least squares method was used as the dependent variables are quantitative in nature, moreover, the study does 
not aim to document the equilibrium state at which the dependent and independent variables equal because of the independent variables' qualitative nature. The variables are qualitative when the dependent variable is dichotomous in nature, thus exhibiting a binary outcome. Hence, the models do not satisfy the conditions to adopt simultaneous equation or any other techniques, as this method is best based on a quantitative nature.

Olomola (2000) used this regression model to hypothesize using eleven variables, which were keys in determining borrowers' repayment status, including: the enterprise's years of existence, the proportion of primary education, the proportion of secondary education, the loan size (amount), disbursement lag, number of visits (loan supervision), years of loan borrowing experience, the amount of savings mobilized in previous years, members' regularity at meetings, and the percentage of members with farming as their primary occupation. These variables are similar to those used in this study, except for some changes necessary to avoid problems of multicollinearity.

\section{Results and discussion}

The microcredit finance group members' socio-economic characteristics

The group's membership formation occurred without a bias toward the individual members' socio-economic characteristics. Table 1 indicates that $70 \%$ of the respondents were female and $30 \%$ were male, revealing that women are more actively involved in microcredit groups and agricultural production. Of the respondents, $73 \%$ were married, $20 \%$ were single, and $7 \%$ included single-parent families. However, $73 \%$ of the respondents had household sizes ranging from 6 to10 people while 17\% had 11 to 15 .

The survey also notes that a majority of respondents, or $57 \%$, completed secondary school, while $34 \%$ had a primary education and $9 \%$ hold higher-degree certificates. Of the respondents, $65 \%$ were between 30 to 49 years of age, while others were older than 49 years of age, revealing the respondents as financially and economically efficient middle-aged men and women. The table also demonstrates that $49 \%$ of the respondents were involved in farming and trading, while $37 \%$ were solely involved in farming. Regarding annual income, $28 \%$ of the respondents made less than N200, 000, while $59 \%$ had an annual income ranging between N200, 001 - N400, 000. Regarding the number of years in the locality, $72 \%$ of the respondents had lived in their locality for approximately $11-20$ years, while $18 \%$ had stayed for approximately $1-10$ years. It is observed that the length of stay in a community increases common neighborliness, which will further strengthen social cohesion and moral bonds.

\section{Groups' and members' operational characteristics}

Table 2 displays the microcredit finance groups' mean characteristics. According to this table, the microcredit finance groups involved in this study had existed for between 2 to 18 years, with a mean of 8 years of existence. These groups have mobilized their members' rural savings, ranging from N250, 000 to N600, 000. These also provide loans to members for durations ranging from 3 to 12 months, with a mean duration of 6 months, and they achieved an average loan recovery of approximately 91\%. Interest on loans ranged from $8 \%$ to $70 \%$, with a mean of $40 \%$. Enimu, Igiri and Achike (2016), also noted that high interest rate are a major challenge facing the individual beneficiaries of Nigeria's microfinance banks loans. 
Table 1 Group Members' Characteristics

\begin{tabular}{|c|c|c|}
\hline Variables & Frequency $(n=288)$ & $(\%)$ \\
\hline \multicolumn{3}{|l|}{ Sex: } \\
\hline Male & 86 & 29.86 \\
\hline Female & 202 & 70.14 \\
\hline \multicolumn{3}{|l|}{ Marital Status: } \\
\hline Single & 57 & 19.79 \\
\hline Married & 209 & 72.57 \\
\hline Divorced/Widow & 22 & 7.61 \\
\hline \multicolumn{3}{|l|}{ Household Size: } \\
\hline $1-5$ & 21 & 7.29 \\
\hline $6-10$ & 211 & 73.26 \\
\hline $11-15$ & 48 & 16.67 \\
\hline Above 16 & 8 & 2.78 \\
\hline \multicolumn{3}{|l|}{ Educational Level: } \\
\hline Primary School & 97 & 33.68 \\
\hline Secondary School & 163 & 56.6 \\
\hline NCE/OND & 15 & 5.21 \\
\hline HND/B.SC & 11 & 3.82 \\
\hline M.SC & 2 & 0.69 \\
\hline \multicolumn{3}{|l|}{ Age of Members } \\
\hline $20-29$ & 20 & 6.94 \\
\hline $30-39$ & 87 & 30.21 \\
\hline $40-49$ & 102 & 35.42 \\
\hline $50-59$ & 61 & 21.18 \\
\hline Above 59 & 18 & 6.25 \\
\hline \multicolumn{3}{|l|}{ Occupation: } \\
\hline Farming only & 107 & 37.82 \\
\hline Farming Plus Trading & 141 & 48.96 \\
\hline Farming Plus Artisanal & 40 & 13.89 \\
\hline \multicolumn{3}{|l|}{ Annual Income (N) } \\
\hline Less than N200,000 & 81 & 28.13 \\
\hline $200,001-300,000$ & 79 & 27.43 \\
\hline $300,001-400,000$ & 92 & 31.94 \\
\hline $400,001-500,000$ & 26 & 9.03 \\
\hline Above 500,001 & 10 & 3.47 \\
\hline \multicolumn{3}{|l|}{ Length of stay in Locality: } \\
\hline $1-5$ & 11 & 3.82 \\
\hline $6-10$ & 41 & 14.24 \\
\hline $11-15$ & 114 & 39.58 \\
\hline $16-20$ & 93 & 32.28 \\
\hline Above 20 & 29 & 10.1 \\
\hline
\end{tabular}

Source: Field Survey, 2016 
Table 2 Microcredit Finance Groups' Mean Characteristics

\begin{tabular}{llll}
\hline Characteristics & Mean & Minimum & Maximum \\
\hline Years of existence (years) & 8 & 2 & 18 \\
Savings mobilization (naira) & N420,000 & N250,000 & N600,000 \\
Loan duration (month) & 6 & 3 & 12 \\
Interest rate (per annum) & 40 & 8 & 70 \\
Membership strength (number) & 13 & 6 & 24 \\
Number of meeting per month & 3 & 1 & 4 \\
Visitation by Credit officer (number) & 8 & 2 & 21 \\
Distance travel to Bank (km) & 15 & 1 & 33 \\
\hline
\end{tabular}

Source: Field Survey, 2016

The mean membership was 13 persons, with the smallest group having 6 members and the largest 24 members. Group meetings occurred at a mean of three times per month, with a range of one to four times per month. Further, a credit officer visited microcredit finance group meetings a mean of eight times, with a minimum of 2 and a maximum of 21 visits. The average distance traveled from the groups' meeting point to a microfinance institution was $15 \mathrm{~km}$, with distances ranging from 1 to $33 \mathrm{~km}$ to the credit source.

The socio-economic determinants of agricultural microcredit finance groups' loan repayments The determinants by nature are known to influence group members' ability to meet their financial obligations to their groups. This study used a multiple regression analysis to analyze the effects of some socio-economic determinants on the members' ability to repay group loans.

The resulting regression equation is as follows:

$$
\begin{aligned}
& \mathrm{LR}=1459.046+50.323 A-343.327 H+112.800 E+.787 M+30.481 D+279.554 C+117.835 S \\
& (1.288)(1.291)^{x}(3.797)^{x x x}(1.124)^{x}(18.861)^{x x x}(.319) \quad(3.390)^{x x x}(2.811)^{x x x} \\
& -21.801 V+284.749 I-0.0071 P-296.687 G-555.175 G D+e^{-} \\
& (.619) \quad(3.275)^{x x x}(2.419)^{x x}(6.717)^{x x x}(1.431)^{x x} \\
& \mathrm{R}^{2}=96 \% \text {, Adj. } \mathrm{R}^{2}=96 \% \text { and } \mathrm{F}-\text { Value }=530.501^{\mathrm{xxx}} \\
& \mathrm{xxx} x \mathrm{x} \text { and }{ }^{\mathrm{x}} \text { - indicate significance at the 1\%,5\% and 10\% levels, respectively. }
\end{aligned}
$$

An evaluation of the model indicates that it performed relatively well based on the $\mathrm{R}^{2}$, adjusted $\mathrm{R}^{2}$ and F-ratio values. The values of $\mathrm{R}^{2}$ and the adjusted $\mathrm{R}^{2}$ are 0.959 (96\%) and 0.957 (96\%) which indicates that approximately $96 \%$ of the variation in the dependent variable (loan repayments) occurred due to the determinants captured in the model. The values of $\mathrm{R}^{2}$, adjusted $\mathrm{R}^{2}$ and $\mathrm{F}$-test thus provided reliable measures of the overall explanatory power of the regression model.

A two-tailed test is used at a $1 \%$ level of significance to reveal the F-computed as 530.501 and the F-table as 2.58. As the calculated F is greater than the corresponding table value, we reject the null hypothesis ( $\mathrm{Ho}$, at $P<0.01$; b's $=0$ ), which states no significant relationship exists between the determinants captured and the group members' loan repayment. Thus, we accept the alternative hypothesis.

Coefficients that were statistically significant and contributed to the specific model were identified by the estimated regression model using their coefficients of determination. 
The significance of the parameter estimate of the model was evaluated by means of $t$-test at $1 \%, 5 \%$ and $10 \%$ levels of significance.

Regarding the parameters included in the model, 10 of the 12 were statistically significant in their effect on loan repayments. These parameters include the group members' age $\left(C_{1}\right)$, household size $\left(C_{2}\right)$, educational level $\left(C_{3}\right)$, amount of credit received $\left(C_{4}\right)$, length of stay in a community $\left(C_{6}\right)$, distance to the credit source $\left(C_{7}\right)$, household income $\left(\mathrm{C}_{9}\right)$, supervision $\left(\mathrm{C}_{10}\right)$, disbursement lag $\left(\mathrm{C}_{11}\right)$ and gender $\left(\mathrm{C}_{12}\right)$.

The coefficient of members' age was significant at $10 \%$ and positively related to the amount of loans repaid. This indicates that the higher the age, the higher the group member's loan repayment rate. This conforms to a priori expectations and parallels the work of Olagunju and Adeyemo (2007), which reported that age positively affects loan repayment. The authors further opined that older borrowers can better obey stated obligations than young people, who have a high propensity to divert loan purposes to other uses, such as substance or, health care without regards to their obligations. This contrasts the work of Eyo, Otu, and Sampson (2008), who reported that loan repayment is more effective among the group's younger members.

The coefficient for household size further conformed to a priori expectations as this was negative and significant at $1 \%$. Therefore, this implies that as the size of the household increases, loan repayment decreases, subsequently increasing loan defaults. More household members mean increased needs, such as health care, education, and clothing. Therefore, if the household size is large, the head of the house is likely to divert the loan causing a default in repayment. A small household size, and the skilled knowledge and managerial expertise derived from an increase in educational level will ensure an efficient utilization of borrowed funds and subsequent repayment. This result is also in accord with studies by Eyo, Otu, and Sampson (2008); Olagunju and Adeyemo (2007); and Enimu, Igiri and Achike (2016).

Education which involves the number of years of schooling, also conformed to a priori expectations with a positive coefficient, and is significant at $10 \%$. This implies that the greater the group members' number of school years, the higher the loan repayment. Literate borrowers repay more of the loans obtained than those who are illiterate, as the former understand the advantages of prompt loan repayment and do not regard such a loan as an entitlement. This result also conforms to findings by Paxton (1996); Olomola (2000), and Enimu and Ohen (2017).

The amount of credit received had a positive coefficient, and is significant at $1 \%$ level, suggesting an increase in loan repayment as the loan amount increases. This conforms to a priori expectations and also agrees with results from Olomola (2002), who noted that amount of loan borrowed was a major determinant of loan repayments. This is possibly due to the advantages associated with economies of scale, which occur through expansions in production and purchase of farm equipments.

The coefficient of length of stay in a community was significant at $1 \%$ level and positively related to loan repayment. Which indicates that the higher the length of stay in a particular community, the higher the loan repayment rate. This parallels a priori expectations and conforms to Afolabi's (2010) results, which reveal that the length of stay in a community/experience positively relates to loan repayment. The author further stresses that, the length of stay in a community determines social cohesion and group 
membership trust, which is vital for loan repayment. This also mirrors work by Olagunju and Adeyemo (2007), and Eyo (2008).

In contrast, and against a priori expectations, the distance to the credit source was significant at the $1 \%$ level and positively related to loan repayment. This result implies that, the longer the beneficiaries' distance to the credit source, the higher the loan repayment. This is possibly because the group's socio and homogeneous characteristics bind group members together, thereby reducing the unwillingness to repay loans.

Household income had a positive coefficient and significance at the $1 \%$ level, demonstrating that the higher the household income, the higher the repayment rate. This result indicates that a higher household income means more money will be available for the head of household, which will likely be available for the repayment of loans. This result conforms to findings from Arene (1992), and Afolabi (2010).

Loan supervision displayed a positive coefficient and was significant at the $1 \%$ level which implies that the more loans were supervised, the more farmers could repay their loans. This conforms to a priori expectations as well as work by Olagunju and Adeyemo (2007), who reported that, a higher probability of more loan repayment exists when loan agents visit loan beneficiaries than when they were not visited.

The coefficient of the disbursement lag was significant at the $1 \%$ level, and negatively relates to loan repayment. This indicates that the shorter the disbursement lag, the higher the loan repayment, which also conforms to a priori expectations. This result also parallels with reports by Arene (1992), and Okorie (1986), who opined that a lower disbursement lag encourages the timely utilization of loans; this invariably leads to high efficiency and output.

Moreover, the coefficient of gender was significant at 5\%levels, and negatively related to the amount of credit repaid. This implies that the group member's gender whether male or female, play a significant role in the loan repayment rate. The negative sign implies that females repay their loans more than their male counterparts. This result conforms to work by Olagunju and Adeyemo (2007), and Ugbomeh, Achoja, Ideh, and Ofuoku (2008).

\section{Conclusion}

Measures are continuously being adopted to ensure agricultural loans' performance, and especially with microcredit finance loans. Many financial institutions' lending programs, designed to boost poor farmers' access to credit, reflect a preference for a group approach rather than an individual approach. This creates a hardship for both the borrower and the lender regarding the excessive transaction costs. If individuals collaborate, transaction costs are expected to decrease, but not all cost components will be minimized unless the individuals' characteristics are carefully examined. Therefore, it is important for lenders to consider the group members' socio-economic determinants to ensure sustained repayment advantages. Credit institutions and microcredit groups should carefully examine the significant determinants of group members' loan repayments in an effort to sustain their viability.

Acknowledgements

We acknowledge the management of university of calabar, Nigeria, and the south western university for their various roles in the publication. 
Authors' contributions

All authors contributed to the success of the research work.

\section{Competing interests}

We declare that the article be publish in your journal and agreed on the principles established by Springer Open and there are no competing interest what so ever.

\section{Publisher's Note}

Springer Nature remains neutral with regard to jurisdictional claims in published maps and institutional affiliations.

Received: 8 May 2017 Accepted: 10 October 2017

Published online: 17 October 2017

\section{References}

Afolabi JA (2010) Analysis of loan repayment among small-scale farmers in Oyo state. Journal of Social Science 22(2):115-119 Ajakaiye DO (2013) Financial Inclusion in Nigeria: Measurement and Lessons. Bullion 36(3):61

Allen F, Demirguc-Kunt A, Klapper L, Martinez-Peria MS (2012) Policies to expand financial inclusion. In: Development research group. The World Bank, Washington D.C

Arene CJ (1992) Loan repayment and technical assistance among small-holder maize farmers in Nigeria. Africa Review of Money, Finance and. Banking:63-74

Aryeety E, Udry C (1997) The characteristics of informal Financial Markets in sub-Saharan Africa. J Af Econ (AERC Supplement) 6:161-203

Aterido, R., T. Beck and L. Lacovone (2011). "Gender and finance in sub-Saharan African: are women disadvantaged?." policy research working paper 5571. The World Bank, Washington D.C.

Campbell T (2006) Household finance. J Financ 61(4):553-604

Demirguc -Kunt A, Klapper L (2012) Measuring financial inclusion: the global Findex database. In: Policy research working paper 6025. Washington D.C, The World Bank

Enimu S, Igiri J, Achike Al (2016) Analysis of the effects of microfinance banks loans on the livelihood of small-holder farmers in Delta state, Nigeria. Journal of economic Affairs (EA) 61(3):381-390

Enimu S, Igiri J, Uduma IS (2015) An assessment of the performance of community banks in financing resource poor farmers in Delta state. International Research Journal of Marketing and Economics 2(10):64-75

Enimu S, Ohen SB (2017) Effect of membership homogeneity on the design and performance of formal agricultural microcredit finance groups in Delta state, Nigeria. Journal of Agricultural Economics, Extension and Rural. Development 5(6):649-657

Eyo EO (1997) Adaptation of Cooperative Structures for Sustainable Agricultural Investment in Akwa Ibom State,Nigeria. Nigerian Journal of Rural Development and Cooperative 5(7):36-43

Eyo EO (2008) Determinants of success of microfinance schemes serving the agricultural sector in Akwa-lbom state, Nigeria. The. Soc Sci 3(1):173-176

Eyo OE, Enimu S. (2015). Financing Agriculture to Support Economic Development in Nigeria: The Need for Banks to Re-Strategies. FAMAN 29 Annual Conference, Dutse, November, 23-26

Eyo EO, Otu JO, Sampson MG (2008) Homogeneity in group membership social characteristics and loan recovery: implications for success of formal-informal sector linkage in Akwa-lbom state, Nigeria. The. Soc Sci 3(7):17-22

Eyo EO (2002) The Model for Linking Savings and Credit Groups with Banks in Akwa-lbom State, Nigeria. Global J. Pure Applied Sci, 8:245-251.

Ghatak M (1999) Group leading, local information and peer selection. J Dev Econ 60:27-50

Hulme D, Mosely P (1996) Finance against poverty II, 1st edn. Routledge, New York, USA

Igben MS, Enimu S (2016) Generating capital accumulation for farm growth in rivers state, Nigeria: the cooperative experience. $17^{\text {th }}$ annual National Conference, Nigerian Association of Agricultural Economists. $17-20^{\text {th }}$. Oct:687-691

Mbah, S. O. (2009), The impact of credit utilization on productivity of small-scale farmers in Ishiala Ngwa north L. G. A Of Abia state. FAMAN 23 annual conference, Umudike, July 25-27

Mkpado M, Idu MA, Arene CJ (2010) Effects of membership homogeneity on the performance of agricultural microcredit groups in rural credit markets, Nigeria. Pakistan Journal of Social Science 7(4):304-317

Nagarajan G, Meyer RI, Graham DH (1999) Does membership homogeneity matter for group-based financial services? Evidence from the Gambia. Afr Dev Rev 11(1):87-102

Okafor FO (2000) Microcredit: an instrument for economic growth and balance development. The Nigerian Banker, July/December, pp 38-45

Okorie A (1986) Major determinants of agricultural small-holder loan repayment in a developing economy: empirical evidence from Ondo state, Nigeria. Agric Adm 21:223-234

Olagunju Fl, Adeyemo R (2007) Determinants of repayment decision among small-holder's farmers in Ogbomosho agricultural zone of Oyo state, Nigeria. Journal of Social Science 4(5):677-686

Olomola AS (2000) Effects of membership homogeneity on the design and performance of informal finance groups in rural Nigeria. Final Research Report Submitted to AERC. Nairobi, Kenya

Olomola, A. S. (2002), Social capital, microfinance group performance and poverty implication in Nigeria. Nigerian Institute of Social and Economic Research (NISER), Ibadan

Oludimu O (1983) The demand for institutional credit in the rural sector of Nigeria: some considerations. Savings and. Development 7:139-150

Paxton, J. A. (1996), Determinants of Successful group loan repayment: An Application to Burkina Faso, Ph.D. Dissertation, the Ohio State University

Schreiner M, Nagarajan G (1997) Predicting creditworthiness with publicly observable characteristics evidence from ASCRA's and ROSCA's in Gambia, Savings and Development, 4 (XXII). In: 399-412 
Sharma M, Zeller M (1997) Repayment performance in group-based credit programs in Bangladesh: an empirical analysis. World Dev 25(10):1731-1742

Slover, C. H. (1991), The effects of membership homogeneity on group size, fund mobilization and engenderment of reciprocal obligations among informal financial groups in rural Zaire paper presented at the seminar on finance and rural development in West Africa Osu/CIRAD

Soren H (2002) Household, Group and Programme Factors in Group-Based Agricultural Credit Delinquency. Ripon College, USA, p 43

Udo, U. O.(1995) Managing Self-help Groups Linkage with Banks for effective savings mobilization and credit delivery". (Paper Presented at a National Workshop on Managing SHGs linkage with Banks; at UYo 4-8 September, 1995)

Ugbomeh MM, Achoja FO, Ideh V, Ofuoku AU (2008) Determinant of loan repayment performance among women self help groups in Bayelsa state, Nigeria. Agricultural Conspectus Scientificus 73(3):189-195

World Bank (2000) Rural Financial Markets in Nigeria, focus note on the issues and. Options, World Bank Rural Development

Yunus M (1999) The Grameen Bank. Sci Am 281(5):114-119

Submit your manuscript to a SpringerOpen ${ }^{\circ}$ journal and benefit from:

- Convenient online submission

- Rigorous peer review

- Open access: articles freely available online

- High visibility within the field

Retaining the copyright to your article

Submit your next manuscript at $\gg$ springeropen.com 